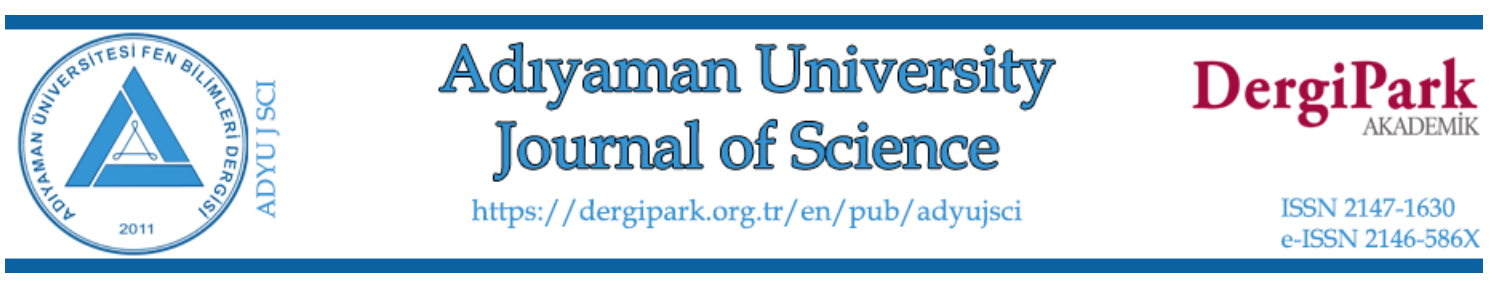

\title{
Effect of Angiogenesis Related Growth Factors VEGF-a and FGF-1 on
}

\section{Osteosarcoma Cell Proliferation}

\author{
Meltem ALPER ${ }^{1, *}$ \\ ${ }^{1}$ Aksaray University, Department of Botanical and Animal Production, Aksaray, Turkey \\ meltemalper@aksaray.edu.tr,ORCID:0000-0001-6359-9979
}

\begin{tabular}{lll}
\hline Received: 12.06 .2020 & Accepted: 10.09.2020 & Published: 30.12 .2020
\end{tabular}

\begin{abstract}
Osteosarcoma is the most common bone tumor in children and adolescents. Alterations in the expression of some genes, cytokines and growth factors are responsible for the development of the malignant phenotype in osteosarcoma. Some members of the VEGF and FGF families have been associated with poor prognosis and the metastasis in various tumor types including osteosarcoma. Among the members of the family, information about effects of VEGF-a and FGF1 on osteosarcoma cell proliferation is limited.

In the present study, it was aimed to elucidate the effects of VEGF-a and FGF-1 on osteosarcoma cell proliferation. Saos-2 cells, having osteoblastic features, were used for osteosarcoma model. Cells were treated $20 \mathrm{ng} / \mathrm{mL}$ VEGF-a and FGF-1 after 24 hours of serum starvation. MTT assay was applied to measure cell viability after incubation for 1-72 hours. Results indicated that VEGF-a promoted cell proliferation for all incubation times. Maximum increase was observed after 48 hours of incubation ( 1.7 fold) with a statistically important manner. FGF-1 led to very slight increase in Saos-2 cell proliferation. Consequently, these findings can contribute development of new therapy strategies for osteosarcoma.
\end{abstract}

Keywords: Osteosarcoma; Saos-2; MTT; VEGF-a; FGF-1. 


\section{Anjiyogenez Bağlantılı Büyüme Faktörleri VEGF-a ve FGF-1'in Osteosarkoma Hücre Proliferasyonu Üzerine Etkileri}

\section{$\ddot{O} \mathbf{z}$}

Osteosarkoma çocuklar ve ergenlerde en sık görülen kemik tümörüdür. Bazı genlerin, sitokinlerin ve büyüme faktörlerinin ekspresyonundaki değişiklikler osteosarkomada malign fenotipin gelişiminden sorumludur. VEGF ve FGF ailelerinin bazı üyeleri, osteosarkomayı da içeren çeşitli tümör tiplerinde kötü prognoz ve metastaz ile ilişkilendirilmiştir. Ailenin üyelerinden VEGF-a ve FGF-1'in osteosarcoma hücre proliferasyonuna olan etkileri hakkında bilgiler sinırlıdır.

$\mathrm{Bu}$ çalışmada VEGF-a ve FGF-1'in osteosarkoma hücre proliferasyonu üzerindeki etkilerinin aydınlatılması amaçlanmıştır. Osteosarkoma modeli olarak osteoblastik özelliklere sahip Saos-2 hücreleri kullanıldı. Hücreler, 24 saatlik serum açlı̆̆ından sonra 20 ng/mL VEGF-a ve FGF-1 ile muamele edildi. 1-72 saat inkübasyon süresinden sonra hücre canlılığını ölçmek için MTT testi uygulandı. Sonuçlar VEGF-a'nın tüm inkübasyon süreleri için hücre proliferasyonunu arttırdığını gösterdi. Maksimum artış, istatistiksel olarak anlamlı bir şekilde, 48 saatlik inkübasyon (1.7 kat) süresinden sonra gözlendi. FGF-1, Saos-2 hücre proliferasyonunda çok küçük bir artışa yol açtı. Sonuç olarak, bu bulgular osteosarkom için yeni tedavi stratejilerinin geliştirilmesine katkıda bulunabilir.

Anahtar Kelimeler: Osteosarkoma; Saos-2; MTT; VEGF-a; FGF-1.

\section{Introduction}

Osteosarcoma is a highly malignant primary bone tumor characterized by aggressive growth and early metastatic potential, which mainly affects children and adolescents [1-5]. Immature bone or osteoid tissue formation are characteristic features of the osteosarcoma. Lung and bone are the most common metastasis sites $[6,7]$. Metastasis leads to poor prognosis for tumor progression. Current therapies have quite a few effects on metastatic osteosarcoma patients $[8,9]$. Therefore, elucidation of the molecular mechanisms underlying osteosarcoma pathogenesis and metastasis may be beneficial for developing more effective treatment strategies [10]. Cells with different levels of differentiation lead to heterogeneous tissue formation in bone. Tissue heterogeneity is closely related to the success of the response to treatment. Cytokines can affect cancer formation, progression, and metastasis at different stages $[1,11,12]$. While some cytokines have been used for cancer treatment, some of them contribute to advanced cancer development 
[13-16]. Understanding of the cytokine networks in oncogenesis has prognostic importance for the course and progression of osteosarcoma [17].

Vascular endothelial growth factor (VEGF) is a member of a large growth factor family and has a critical function for the induction of the angiogenesis. Angiogenesis is a key regulator for tumor development and metastasis. It has been shown that increased VEGF expression is related to poor prognosis in many tumor types [18-26]. It has been reported that VEGF variants and their receptors were expressed in osteosarcoma cells and promote tumor angiogenesis [2729].

FGF-1 (Fibroblast Growth Factor) is another important factor related to tumorigenesis, epithelial-to-mesenchymal transition, as well as invasion and metastasis. Dysregulation of the FGF receptors has been reported in many cancer types such as urothelial carcinoma, hepatoma, ovarian cancer, and lung adenocarcinoma. Clinical studies have been indicated that blocking the FGF/FGFR signaling may enable the development of a new strategy for the treatment of various human cancers. Therefore, numerous FGFR inhibitors were developed for therapy [30-33]. The effect of some FGF family members on osteosarcoma progression has been investigated so far. For instance, it has been reported that upregulation of the FGF-5 induces osteosarcoma cell proliferation [34].

Although critical functions of some cytokines have been determined on the pathogenesis of the osteosarcoma, little is known about angiogenesis-related growth factors VEGF-a and FGF1 on the contribution of osteosarcoma proliferation. The current study is aimed to investigate the antiproliferative effect of these growth factors on osteosarcoma. Saos-2 cell model, displaying osteoblastic features, was used for proliferation studies. Cells were treated $20 \mathrm{ng} / \mathrm{mL}$ of VEGF- $\alpha$ and FGF-1 and cell viability was measured using the MTT method. Our findings will provide new insights for the development of new therapeutic approaches for osteosarcoma.

\section{Materials and Methods}

\subsection{Cells and reagents}

Saos-2 (Human osteosarcoma) cell line was a gift from Dr. Kenneth Wann (Cardiff, School of Biosciences, Cardiff UK). Cell culture media and reagents; DMEM (Dulbecco's Modified Eagle's Medium) and PBS (Phosphate Buffer Saline) tablets were purchased from Sigma, FCS (Fetal Calf Serum) was purchased from Invitrogen, VEGF-a and FGF-1 were purchased from Peprotech, MTT (Thiazolyl Blue Tetrazolium Bromide) and other chemicals that were used in the study were purchased from Sigma. 


\subsection{Cell culture and MTT assay}

Saos- 2 cells were grown in DMEM containing $10 \%$ FCS and $2 \mathrm{mM} \mathrm{L-Glutamine}$ and maintained in a humidified incubator at $37^{\circ} \mathrm{C}$ containing $5 \%(\mathrm{v} / \mathrm{v}) \mathrm{CO}_{2}$ in air. The effect of VEGFa and FGF-1 on cell viability was assessed by the MTT method. Briefly, Saos- 2 cells were plated out in 96-well plastic plates at a concentration of $5 \times 10^{4}$ cells per well and stimulated with 20 $\mathrm{ng} / \mathrm{mL}$ of VEGF-a and FGF-1 for 1, 24, 48, and $72 \mathrm{~h}$. Untreated groups were used as control. MTT solution was added to the cells after indicated incubation time intervals. Formazan crystals were solubilized with $200 \mu \mathrm{l}$ Isopropanol including $0.01 \%$ per well and the optical density (OD) at $550 \mathrm{~nm}$ was measured with a spectrophotometric microplate reader (Thermo Scientific). The mean OD value of the control groups was subtracted from the OD value of each cytokine treated groups for all incubation times. Experiments were performed for three times [35].

\subsection{Statistical analysis}

Statistical analyses were performed using Mini Tab 14. Standard deviations and $\mathrm{p}$ values were calculated using One-way Anova analysis. Statistical significance was taken as $p \leq 0.05$. Data are representative of average results from independent experiments carried out at least three times and are expressed as the mean \pm standard deviation [36].

\section{Results}

\subsection{Effect of VEGF-a and FGF-1 on Saos-2 cell proliferation}

To determine the effect of VEGF-a and FGF-1 on osteosarcoma proliferation we used Saos2 (Sarcoma osteogenic) cell line for in vitro model. These cells are well characterized primary osteosarcoma model that is commonly used in bone cancer research for the late osteoblastic differentiation stage [37, 38]. Cells were serum-starved for $24 \mathrm{~h}$ using $0.1 \%$ BSA before the growth factor treatment to observe the effect more clearly. Saos-2 cells were treated with 20 $\mathrm{ng} / \mathrm{mL}$ of VEGF-a and FGF-1 for 1-72 hours. MTT analysis was performed as described in Section 2.2 after indicated time intervals. VEGF-a treatment increased Saos-2 cell proliferation for all time intervals. According to statistical analysis, a maximum increase in cell proliferation was observed after 48 hours of incubation (1.7-fold). 


\section{$20 \mathrm{ng} / \mathrm{mL}$ VEGF-a}

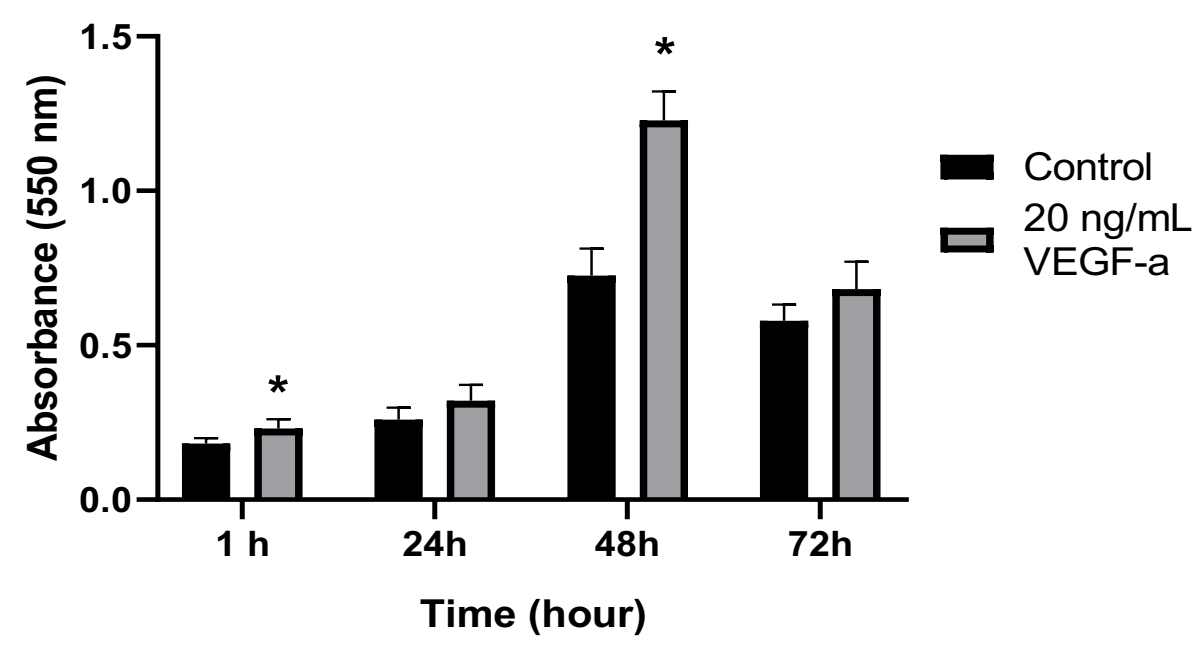

Figure 1: Effect of $20 \mathrm{ng} / \mathrm{mL}$ of VEGF-a treatment on Saos-2 cell proliferation. Untreated cells were used as the control for 1, 24, 48, and $72 \mathrm{~h}$. Statistical analysis was carried out by ANOVA (one way) (Statistical significance was taken as $* \mathrm{p} \leq 0.05)$. The image shown is average results from independent experiments carried out at least three times

We also assessed the proliferative effect of the other angiogenesis-related growth factor FGF-1 on Saos- 2 cells by MTT as described above. Treatment of the Saos- 2 cell with $20 \mathrm{ng} / \mathrm{mL}$ of FGF-1 led to a very slight increase in cell proliferation. A maximum increase was observed after 72 hours of incubation (1.2 fold).

\section{$20 \mathrm{ng} / \mathrm{mL}$ FGF-1}

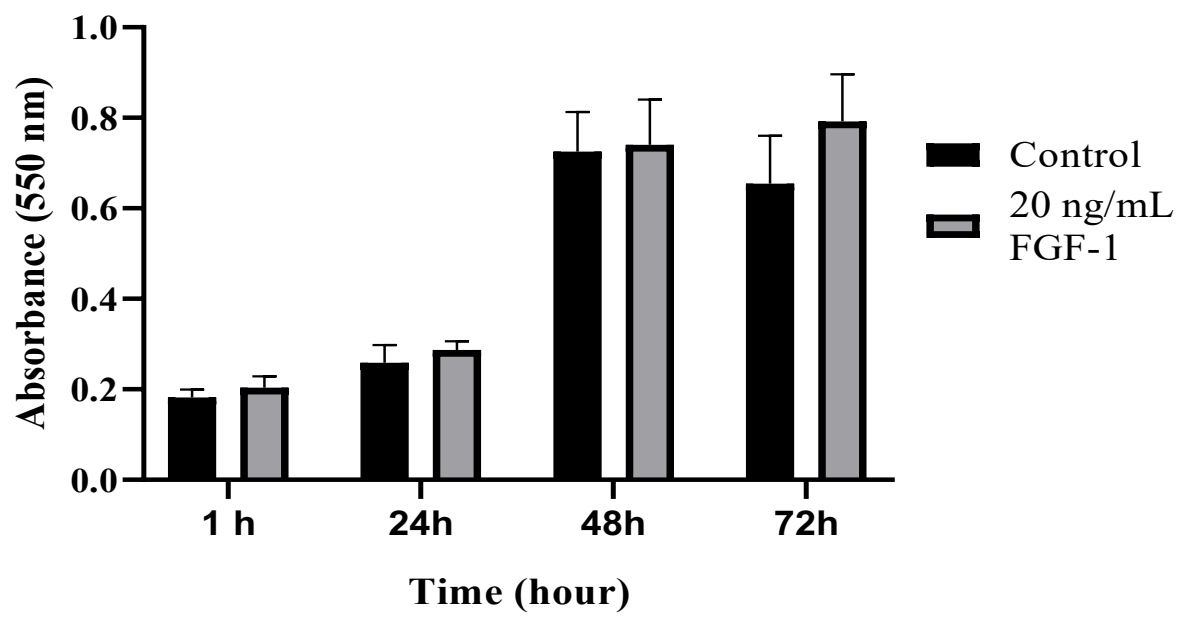

Figure 2: Effect of $20 \mathrm{ng} / \mathrm{mL}$ of FGF-1 treatment on Saos-2 cell proliferation. Untreated cells were used as control groups for the indicated time. The p-value was calculated by ANOVA (one way) analysis $(p>0.05)$. The image shown is the average results from independent experiments carried out at least three times 


\section{Discussion}

The development of new blood capillaries is an important issue for tumor growth and metastasis [1]. Angiogenesis involves whole processes of the malignant osteosarcoma. VEGF, aFGF and bFGF are angiogenesis-related growth factors and released from tumor tissues and contribute to tumor progression. They have the ability to stimulate angiogenesis under hypoxic conditions. VEGF promotes cell migration by initiating a variety of signaling pathways. It is also a mediator of vessel permeability and enables endothelial progenitor cells to migrate from the bone marrow to neovascularization sites. It has been reported that increased VEGF production is important in the growth of solid tumors including osteosarcoma. Peng and colleagues were determined that silencing of the VEGF inhibited osteosarcoma growth and angiogenesis in Wistar rat model. Besides, they were established that the silencing of VEGF expression could promote apoptosis in Saos-2 cells [29, 39]. VEGF-a mainly conducts its pro-angiogenic activities through VEGFR-2 (VEGF receptor 2). Because of its critical role in tumor angiogenesis, the VEGF/VEGFR pathway has become a therapeutic target in cancer research [39, 40].

The human FGF family includes 23 members and they are expressed in many tissues. FGFs regulate a broad spectrum of physiological and pathological processes, including development, wound healing and neoplastic transformation. Further, FGFs play important roles in tumorigenesis increasing cell migration and invasion. For instance, FGF2, has angiogenic potential and promote tumor angiogenesis [42]. Shimizu and colleagues have determined that FGF-2 has function maintaining the aggressive profile of the osteosarcoma affecting cellular immaturity They have suggested that blocking of growth factor signaling pathways including FGF-2, might be useful in controlling the aggressiveness of osteosarcoma [1]. Han and colleagues reported a significant upregulation in FGF-5 expression levels in osteosarcoma cell models and patient tissues, compared to control cells and healthy tissues. Further, they presented evidence on FGF5 promoted osteosarcoma cell proliferation [34]. The FGFs promote tumor progression through specific (FGFR) FGF receptor signaling. The expression of FGFR genes has been detected in osteosarcoma, such as FGFR1, FGFR2, and FGFR3. However, the expression profile of FGFRs differs among the osteosarcoma cell models. FGFR1 expression is associated with poor response to chemotherapy in osteosarcoma. High expression levels of FGF2 and its receptor FGFR3 have been found in osteosarcoma and are significantly related with poor prognosis [4].

FGF1 has been determined as a proliferative factor for human preadipocytes and IEC-6, Caco-2, and HT-29 cell lines [43]. Although the proliferative effects of FGFs on different cell types have been studied, the effect of FGF-1 on osteosarcoma cell proliferation is unknown. 
Because of the critical roles of the VEGF and FGF family on tumor growth and progression antiproliferative effect of these growth factors on the osteosarcoma was assessed. VEGF-a promoted Saos- 2 cell proliferation gradually up 1.7 fold for 48 hours. This proliferative effect was started to decrease after 72 hours of incubation. FGF-1 had a slight effect on the proliferation of the osteosarcoma cells. In conclusion, in this work, we demonstrated that treatment of Saos-2 osteosarcoma cell with VEGF-a and FGF-1 in the absence of other growth factors activated cellular proliferation. These effects could contribute to the poor prognosis of osteosarcoma. Overexpression and/or silencing studies will provide more direct evidence for the contribution of these factors to osteosarcoma development.

\section{Acknowledgement}

Saos-2 cells were kindly provided by Dr. Kenneth Wann and (Cardiff, School of Biosciences, Cardiff UK).

\section{References}

[1] Shimizu, T., Ishikawa, T., Iwai, S., Ueki, A., Sugihara, E., Onishi, N., Kuninaka, S., Miyamoto, T., Toyama, Y., Ijiri, H., Mori, H., Matsuzaki, Y., Yaguchi, T., Nishio, H., Kawakami, Y., Ikeda, Y., Saya, H., Fibroblast growth factor-2 is an important factor that maintains cellular immaturity and contributes to aggressiveness of osteosarcoma, Molecular Cancer Research, 10, 454-468, 2012.

[2] Bielack, S.S., Kempf-Bielack, B., Delling, G., Exner, G.U., Flege, S., Helmke, K., Kotz, R., Salzer-Kuntschik, M., Werner, M., Winkelmann, W., Zoubek, A., Jürgens, H., Winkler, K., Prognostic factors in high-grade osteosarcoma of the extremities or trunk: an analysis of 1,702 patients treated on neoadjuvant cooperative osteosarcoma study group protocols, Journal of Clinical Oncology, 20,776-90, 2002.

[3] Clark, J.C.M., Dass, C.R., A review of clinical and molecular prognostic factors in osteosarcoma, Jornal of Cancer Research and Clinical Oncology,134, 281-97, 2008.

[4] Zhou, W.Y., Zheng, H., Du, X.L., Yang, J.L., Characterization of FGFR signaling pathway as therapeutic targets for sarcoma patients, Cancer Biology and Medicine, 13,260-8, 2016.

[5] Baird, K., Davis, S., Antonescu, C.R., Harper, U.L., Walker, R.L., Chen, Y., Glatfelter, A.A., Duray, P.H., Meltzer, P.S., Gene expression profiling of human sarcomas: Insights into sarcoma biology, Cancer Research, 65, 9226-35,2005.

[6] Xu, C.J., Song, J.F., Su, Y.X., Liu, X.L., Expression of b-FGF and endostatin and their clinical significance in human osteosarcoma, Orthophedic Surgery, 2, 291-8, 2010.

[7] Berhe, S., Danzer, E., Meyer, P., Behr, G., LaQuaglia, M.P., Price, A.P., Unusual abdominal metastases in osteosarcoma, Journal of Pediatric Surgery Case Reports, 28, 13-16, 2018

[8] Shih, C.H., Chiang, T.B., Wang, W.J., Synergistic suppression of a disintegrin acurhagin-C in combination with AZD4547 and reparixin on terminating development for human osteosarcoma MG-63 cell, Biochemical and Biophysical Research Communications, 492, 513519,2017 . 
[9] Mirabello, L., Troisi, R.J., Savage, S.A., International osteosarcoma incidence patterns in children and adolescents, middle ages and elderly persons, International Jornal of Cancer, 125, 229-234, 2009.

[10] Li, Y., Zhang, J., Ma, D., et al., Curcumin inhibits proliferation and invasion of osteosarcoma cells through inactivation of Notch-1 signaling, FEBS Journal, 279(12), 22472259, 2012.

[11] Goldszmid, R.S., Trinchieri, G., The price of immunity, Nature Immunology, 13, $932-$ 938, 2012.

[12] Turtle, C.J., Hudecek, M., Jensen, M.C., Riddell, S.R., Engineered T cells for anticancer therapy, Current Opinion in Immunology 24, 633-639, 2012.

[13] Dunlop, R.J., Campbell, C.W., Cytokines and advanced cancer, Journal of Pain and Symptom Management, 20 (3) ,214-232, 2000.

[14] Negus, R.P.M., Balkwill, F.R., Cytokines in tumour growth, migration and metastasis, World Journal of Urology, 14,157-165, 1996.

[15] Zumkeller, W., Schofield, P.N., Growth factors, cytokines and soluble forms of receptor molecules in cancer patients, Anticancer Research, 15, 344-348,1995.

[16] Fridman, W.H., Tartour, E., The use of cytokines in the treatment of solid tumours, Haematolgy, Transfusion and Cell Therapy, 39,105-108, 1997.

[17] Savitskaya, Y.A., Rico-Martínez, G., Linares-González, L.M., Delgado-Cedillo, E.A., Téllez-Gastelum, R., Alfaro-Rodríguez, A.B., Redón-Tavera, A., \& Ibarra-Ponce de León, J.C., Serum tumor markers in pediatric osteosarcoma: a summary review, Clinical Sarcoma Research, $2,9,2012$

[18] Koch., S., Claesson-Welsh, L., Signal transduction by vascular endothelial growth factor receptors, Cold Spring Harbor Perspectives in Medicine, 2, a006502, 2012.

[19] Carmeliet, P., Jain, R.K., Angiogenesis in cancer and other diseases, Nature 407, 249257,2000

[20] Folkman, J., Role of angiogenesis in tumor growth and metastasis, Seminars in Oncology, 29, 15-18, 2002.

[21] Ferrara, N., Carver-Moore, K., Chen, H., Dowd, M., Lu, L., O'Shea, K.S., PowellBraxton, L., Hillan, K.J., Moore, M.W., Heterozygous embryonic lethality induced by targeted inactivation of the VEGF gene, Nature, 380,439-442, 1996.

[22] Ahluwalia, A., Jones, M.K., Matysiak-Budnik, T., Tarnawski, A.S., VEGF and colon cancer growth beyond angiogenesis: does VEGF directly mediate colon cancer growth via a nonangiogenic mechanism?, Current Pharmaceutical Design, 20,1041-1044, 2014.

[23] Hata, K., Watanabe, Y., Nakai, H., Hata, T., Hoshiai, H., Expression of the vascular endothelial growth factor (VEGF) gene in epithelial ovarian cancer: an approach to anti-VEGF therapy, Anticancer Research, 31, 731-737, 2011.

[24] Yu, X.W., Wu, T.Y., Yi, X., Ren, W.P., Zhou, Z.B., Sun, Y.Q., Zhang, C.Q., Prognostic significance of VEGF expression in osteosarcoma: a meta-analysis, Tumor Biology, 35,155-160, 2014.

[25] Zhuang, Y., Wei, M., Impact of vascular endothelial growth factor expression on overall survival in patients with osteosarcoma: a meta-analysis, Tumor Biology, 35, 1745-1749, 2014. 
[26] Han, G., Wang, Y., Bi, W., Jia, J., Wang, W., Xu, M., Effects of vascular endothelial growth factor expression on pathological characteristics and prognosis of osteosarcoma, Clinical and Experimental Medicine, 16(4), 577-584, 2016.

[27] Matsumoto, G., Hirohata, R., Hayashi, K., Sugimoto, Y., Kotani, E., Shimabukuro, J., Hirano, T., Nakajima, Y., Kawamata, S., Mori, H., Control of angiogenesis by VEGF and endostatin-encapsulated protein microcrystals and inhibition of tumor angiogenesis, Biomaterials, 35, 1326-33, 2014.

[28] Baptista, A.M., Camargo, A.F., Filippi, R.Z., Oliveira, C.R., Azevedo Neto, R.S., Camargo, O.P., Correlation between the expression of vegf and survival in osteosarcoma, Acta Ortopedica Brasileria, 22, 250-5,2014

[29] Peng, N., Gao, S., Guo, X., Wang, G., Cheng, C., Li, M., \& Liu, K., Silencing of VEGF inhibits human osteosarcoma angiogenesis and promotes cell apoptosis via VEGF/PI3K/AKT signaling pathway, American Journal of Translational Research, 8(2),1005$1015,2016$.

[30] Dai, S., Zhou, Z., Chen, Z., Xu, G., Chen, Y., Fibroblast Growth Factor Receptors (FGFRs): Structures and Small Molecule Inhibitors, Cells, 8(6), 614, 2019.

[31] Ramos, C., Becerril, C., Montano, M., Garcia-De-Alba, C., Ramirez, R., Checa, M., Pardo, A., Selman, M., FGF-1 reverts epithelial mesenchymal transition induced by TGF- $\{$ beta $\} 1$ through MAPK/ERK kinase pathway, American Journal of Physiolgy Lung Cellular and Molecular Physiolgy, 299, L222-31, 2010.

[32] Jouanneau, J., Plouet, J., Moens, G., Thiery, J.P., FGF-2 and FGF-1 expressed in rat bladder carcinoma cells have similar angiogenic potential but different tumorigenic properties in vivo, Oncogene, 14, 671-6, 1997.

[33] Chudzian, J., Szlachcic, A., Zakrzewska, M., Czub, M., Pustula, M., Holak, T.A., Otlewski, J., Specific Antibody Fragment Ligand Traps Blocking FGF1 Activity, International Journal of Molecular Sciences, 19 (9),2470, 2018.

[34] Han, D., Wang, M., Yu, Z., Yin, L., Liu, C., Wang, J., Liu, Y., Jiang, S., Ren, Z., Yin, J., FGF5 promotes osteosarcoma cells proliferation via activating MAPK signaling pathway. Cancer management and research, 11, 6457-6466, 2019.

[35] Tokay, E., Kockar F., Identification of intracellular pathways through which TGF- $\beta 1$ upregulates URG-4/URGCP gene expression in hepatoma cells, Life Sciences, 144, 121-128, 2016

[36] Kim, H.Y., Analysis of variance (ANOVA) comparing means of more than two groups. Restorative dentistry \& endodontics, 39(1), 74-77, 2014.

[37] Fogh, J., Fogh, J.M., Orfeo, T., One hundred and twenty-seven cultured human tumor cell lines producing tumors in nude mice, Journal of the National Cancer Institute, 59(1), 221226, 1977.

[38] McQuillan, D.J., Richardson, M.D., Bateman, J.F., Matrix deposition by a calcifying human osteogenic sarcoma cell line (SAOS- 2), Bone, 16 (4), 415-26, 1995.

[39] Lu, X., Tao, J., Wei, G., Anti-angiogenesis target therapy for advanced osteosarcoma, Oncology Reports, 38,625-636, 2017.

[40]. Hicklin, D.J., Ellis, L.M., Role of the vascular endothelial growth factor pathway in tumor growth and angiogenesis, Journal of Clinical Oncology, 23, 1011-1027, 2005.

[41] Gazdar, A.F., Kadoyama, C., Venzon, D., Park, J.G., Tsai, C.M., Linnoila, R.I., Mulshine, J.L., Ihde, D.C., Giaccone, G., Association between histological type and 
neuroendocrine differentiation on drug sensitivity of lung cancer cell lines, Journal of National Cancer Institute Monographs 13, 191-196, 1992.

[42] Kwabi-Addo, B., Ozen, M., Ittmann, M., The role of fibroblast growth factors and their receptors in prostate cancer, Endocrine-Related Cancer., 11(4):709-724, 2004

[43] Yun, Y.R., Won, J.E., Jeon, E., Lee, S., Kang, W., Jo, H., Jang, J.H., Shin, U. S., Kim, H.W., Fibroblast growth factors: biology, function, and application for tissue regeneration, Journal of tissue engineering, 2010: 218142, 2010. 